Canadian University Music Review

Canadian University Music Review

Revue de musique des universités canadiennes

\title{
Family Values: The Trapp Family Singers in North America, 1938-1956
}

\section{Michael Saffle}

Volume 24, numéro 2, 2004

URI : https://id.erudit.org/iderudit/1014583ar

DOI : https://doi.org/10.7202/1014583ar

Aller au sommaire du numéro

\section{Éditeur(s)}

Canadian University Music Society / Société de musique des universités canadiennes

\section{ISSN}

0710-0353 (imprimé)

2291-2436 (numérique)

Découvrir la revue

Citer cet article

Saffle, M. (2004). Family Values: The Trapp Family Singers in North America, 1938-1956. Canadian University Music Review / Revue de musique des universités canadiennes, 24(2), 62-79. https://doi.org/10.7202/1014583ar
Résumé de l'article

Pendant des décennies, les historiens de la musique et les spécialistes de la pratique musicale ont négligé ou ignoré les chanteurs de la famille Trapp. Pourtant, ceux-ci ont obtenu un succès retentissant tout au long des années 1930, 1940 et le début des années 1950, aussi bien au Canada qu'aux États-Unis, en raison des " valeurs familiales " qu'ils véhiculaient. Ces valeurs comprenaient, entre autres, la foi chrétienne des Trapp, les activités de nature patriotique ou caritative, ainsi que la saine représentation rattachée à la vie privée de cette famille, leurs « semaines vocales » et plus de 1800 concerts réalisés publiquement.
All Rights Reserved @ Canadian University Music Society / Société de musique des universités canadiennes, 2005
Ce document est protégé par la loi sur le droit d'auteur. L'utilisation des services d'Érudit (y compris la reproduction) est assujettie à sa politique d'utilisation que vous pouvez consulter en ligne.

https://apropos.erudit.org/fr/usagers/politique-dutilisation/ 


\title{
FAMILY VALUES: THE TRAPP FAMILY SINGERS IN NORTH AMERICA, 1938-1956 ${ }^{1}$
}

\author{
Michael Saffle
}

Musical performance and its reception involve a great deal more than music. As Nicholas Cook has suggested, performances deal with-and depart from-scripts rather than texts; they are (largely) about performers and audiences rather than (exclusively) about the music executed and interpreted (Cook 2003). Cook's arguments call to mind drama theorist Baz Kershaw's assertion that "no item in the environment of performance can be discounted as irrelevant to its impact" (Kershaw 1992, 22). Even what happens off-stage may contribute to this "environment," at least insofar as reputation and reception are concerned.

No wonder, then, that musicians from Paganini and Liszt to the Three Tenors, from minstrel troupes and chorus girls to U2 and the Dixie Chicks, have exploited-unconsciously, inadvertently, or shamelessly-their audiences' prejudices. These and many other successful artists have been hailed not only for their technical and interpretive skills, but also for their politics (as was Ignace Paderewski), ethnicity (as were the Jubilee Singers), and religious convictions (as were Jenny Lind, the Carter Family, and the Lennon Sisters). Lind's Protestant piety and philanthropic activities, for instance, together with published accounts of her "beneficence" and "thirst after the holiest and highest," contributed enormously to the success of her American tours (Ware and Lockard 1980, 64-65). ${ }^{2}$

Extra-musical factors played crucial roles in the remarkable musical career of the Trapp Family Singers. Between 1938, when they arrived in New York City for the first time, and 1956, when they officially retired from touring, the Trapps gave an astonishing 1,800 concerts in the Pacific (including Hawaii) as well as Austria, Canada, and especially the United States. ${ }^{3}$ So overwhelming,

1A preliminary version of the present paper was presented at "Northern Perspectives on Music as a Vehicle for the Transmission of Culture": a conference sponsored jointly by the joint Finnish Musicological Society and the Canadian University Music Society, and held at Turku, Finland; 13-15 May 2003. The author would like to thank Virginia Polytechnic Institute and State University, Blacksburg, for funding that helped him attend the meeting in question.

2 See, too, the New York Home Journal (5 November 1853), where these and other words on behalf of Lind's character first appeared in print.

3Based on assertions, largely confirmed by Musical America advertisements, that the Trapp Family Singers performed as often as 125 times annually during the 1940s and 1950s. See, too Zechner-Kamberger 2000, 101, 103. 
however, has been the impact of The Sound of Music-both as a musical comedy and a feature film - that many Americans today equate its story with the whole of the Trapp family's history. All but forgotten are their appearances with symphony orchestras, their recordings, and their contributions to charitable causes. In other words, the Trapps enjoyed musical successes altogether independent of Rogers's and Hammerstein's tunes and lyrics (Knapp 2004), even though their real-life activities anticipated, or at least did not contradict, the overall sense of The Sound of Music as "family entertainment."

In particular, the Trapps' American reception was shaped by what today are sometimes epitomized as "family values." This phrase cannot be defined in any one way, nor are the attitudes it suggests necessarily synonymous with party politics, "national" prejudices, or gender stereotypes. ${ }^{4}$ Strictly speaking, "family values" need not involve "families" at all..$^{5}$ During the 2004 U.S. presidential elections, for example, "family values" advocates included Christian Conservatives opposed to same-sex marriage and enthusiastic about anti-pornography initiatives and attempts to censor television programming. During the 1940 s and 1950 s, on the other hand, "family values" more often meant patriotism, hard work, and "common decency."

I believe the Trapps' enormous success can only be understood in terms of "values": theirs, and possibly those of their managers. This seems to have been true especially insofar as the Trapps presented and shared themselves as a family throughout their career. Their distinctive brand of "musicking" (to borrow Christopher Small's term) enabled non-family members "to experience" life with the Trapps: to "try on" their attitudes and "see how they fit." Concert-goers were encouraged, actively as well as passively, "to say, to themselves, to one another and to anyone else who may be paying attention: these are our values ... this is who we are" (Small 1998, 183). In response, the Trapps' agents, audiences, and critics consistently and consciously praised (or promoted) them as patriots and good-deed doers as well as performers.

Although the Trapps were skilled musicians, their performing career has been largely forgotten. What remains, as we shall see below, is contemporary testimony, supplemented by reminiscences and a few artifacts, testifying to their carefully scripted public appearances, their unique blend of American, Austrian, and Catholic loyalties, and their contributions to recorder playing

4Evidence suggests, for instance, that American parents were more sympathetic in 1952 to Democratic Party politics; by 1992 they had become more sympathetic to Republican causes. During the same four decades, however, parents and non-parents alike became increasingly cynical about U.S. government politics and practices (Teixeira 2002, 120-27).

5 Perhaps the best sources of information about the various meanings of "family values" is the internet. For many people the phrase stands for nothing more specific than familial "flexibility," "cohesion," and "communication." See http://la.essortment.com/wahtarefamily_ralm.htm [sic]. Others employ the phrase to mean "no prior marriages, no children from prior relationships, [and] no threat or even thought of divorce." See http://www.mcwilliams.com/books/aint/404.htm. The American Family Association supports "traditional family values" largely in terms of opposition to pre-marital sex, "abuses of tax dollars by [the] National Endowment for the Arts," and its own "war on divorce." See http://www.afa.net/about.asp. 
and the popularity of folk music in the United States throughout the 1950s and early 1960 s.

\section{I}

Instead of "ending"-as does The Sound of Music-with their escape from Nazi persecution, the Trapps' musical story really began after their arrival in the United States. ${ }^{6}$ Much of what we know today about the family's New World activities is recorded in several of its members' reminiscences and autobiographies. The Story of the Trapp Family Singers (Trapp 1949), the first and best-known of several books written by matriarch Maria Augusta Trapp, ${ }^{7}$ documents the family's early adventures in Europe and America. Among Maria's reminiscences are those of canon lawyer and musician Father (later, Monsignor) Dr. Franz Matthias Wasner-after 1935, the Trapps' confessor, and throughout their career director of and participant in their many musical activities (Wasner 2000). A Family on Wheels (Trapp 1959) appeared ten years later. Taken together, these reminiscences encapsulate "typical" American immigrant experiences as well as the Trapps' somewhat unusual struggle against complete cultural assimilation (Saffle 2003, 68-82). Furthermore, Maria's Story inspired The Sound of Music-which omits almost everything her books deal with-as well as additional popularizations (e.g., Metten 1981; Wilhelm 1983), plays (e.g., Boriga 1980; Manning 2001), and two 1950s German-language feature films. ${ }^{8}$ Later, Maria described her family's Catholic holiday customs (Trapp 1952) and religious beliefs (Trapp 1955); a third volume, devoted to her own Christian convictions, appeared posthumously (Trapp 2000). Daughter Agathe von Trapp's recent autobiography devotes more attention to her family's pre-American experiences (Trapp 2003).

Maria's autobiographies attribute her family's successes largely to high musical standards and occasional "miracles" as well as a lot of hard work. Her observations, however, do not tell the whole story. Independent, contemporary documentary sources-newspaper and magazine reviews, feature articles, interviews, and especially advertisements for concert tours-suggest that the Trapps, their managers, or both consciously altered and improved the ensemble's repertory and stage deportment to ensure popularity as well as respectability. During the 1940s the Trapps' ensemble singing resonated with patriotic initiatives that encouraged group music-making among Americans. Even their refusal to become altogether assimilated helped confirm the family's reputation for industriousness and uprightness. The Trapps quickly became national

6A captioned photograph describes the Trapps as originally "a choir in Salzburg for home consumption," then adds: "Now they are professional concert artists and begin their second season here next Saturday" (New York Times, 15 October 1939). The Trapps also performed during 1937-1938 in London, Milan, Turin, and Rome (Trapp 2003, 122-26).

7 Most of the Trapps officially dropped the aristocratic "von" from their names in 1948, after becoming American citizens (Wilson 1959, 75).

8Die Trapp-Familie (directed by Joseph Liebeneiner; 1956) and Die Trapp-Familie in Amerika (by the same director; 1958). For additional information about the former film, see Moltke 1996. 
icons of industry, patriotism, good deeds, and that quintessential 1950s conflation: "do-it-yourself togetherness."

The Trapps' Philadelphia and New York debuts were somewhat different from most of their subsequent performances. The family's first Town Hall appearance on 10 December 1938, for example, was successful but ... odd. Their vocal sections included such canonical masterpieces as Bach's challenging motet Jesu, meine Freude, a work they rarely or never sang in public again. Although the Times critic praised their "lovable and appealing" qualities as a family of "modest, serious singers," he also observed that the children's "mellow, well-blended" voices were "not large" (New York Times, 11 December 1938). For Times editors, the fact that family members also ventured to perform publicly on recorders, violas da gamba, and harpsichord was itself considered noteworthy. ${ }^{9}$

After returning a year later to the United States from a tour of Scandinavia, the Trapps were confronted with the necessity of securing regular engagements if they wanted to eat. In spite of their successes, they were advised by one of Maria's friends to "go back to Europe ... before you spend your last dollar. Your art is too subtle. People here will never understand it" (Trapp 1949, 177-78). Frederick C. Schang, Jr., an impresario the family approached in 1939, at first refused to represent them-not for artistic reasons, but because he too felt they lacked audience appeal. According to Maria's first-hand account, Schang (who later became one of the Trapps' managers) ${ }^{10}$ criticized their programming ("That piece by Bach was forty-five minutes [long]!"), their choice of instruments ("Those recorders! They sound like a calliope"), and especially their deportment:

"But by far the worst thing is your appearance-solemn and deadly serious, you come and go like a funeral procession. No charming smile and no good looks, either," and he continued in real disgust: "those long skirts, high necks, hair parted in the middle, braids in the back, shoes like boys, cotton stockings! Can't you get decent store clothes so one can see your legs in nylon stockings, get pretty, high-heeled shoes and put a little red on your face and on your lips?" “No," [Maria Trapp] said gravely, "we can't...." (Trapp 1949, 181-82).

Nevertheless, the Trapp women soon began using makeup-albeit in limited quantities (Trapp 2003, 161-62). Increasingly, too, the Trapps programmed "lighter" fare, especially madrigals, Christmas carols, and folk songs. Family members smiled more often on stage, relied more often on props, and even

9The review's sub-headlines read: "Group Heard in Choral Works of Five Centuries in Its First Appearance Here / Also Play on Recorders" [loc. cit.].

10 In 1950s advertisements, Schang's firm is sometimes identified as Coppicus, Schang, and Brown (F. C. Coppicus was also the founder of the Metropolitan Musical Bureau), sometimes as Columbia Artists Management, Inc. (or CAMI). CAMI and its affiliates did well by with the Trapps. Today, however, the family is omitted from the firm's on-line list of notable artists at http://www.cami. com/about/history.asp. 
"invited" their youngest siblings to join them on stage. Instead of the Trapp Family "Choir," the group advertised itself as the Trapp Family Singers.

The transformation of the seemingly cheerless Choir into the charming Singers took place fairly quickly. In December 1940 the Trapps added a Christmas tree, "candle lanterns," and observations about Austrian customs and the origins of "Silent Night" to the program of carols and shorter works by Palestrina, Monteverdi, and Tchaikovsky they presented at Town Hall (New York Times, 9 December 1940). The following December, another critic reported that "this year ... [even] more of [the family's] selections were in English [and] the Baroness's informal comments were a little more extensive." ("Informal comments" were much less common at classical concerts during the 1940s than they are today.) Johannes, "aged 2-1/2, with his Dutch-bobbed fair hair, also came on for the carols and sat beside his mother"; and the stage was again "decorated with a large Christmas tree hung with tinsel, apples, and bonbons twisted in red paper." Interestingly enough, the same critic also observed that "the singers seem to have lost some of their former spontaneity"; nevertheless, "they remain fine musicians and there was much that was charming and touching on their program" (New York Times, 15 December 1941). In the years that followed, Trapp Family press releases advertised "rollicking folk songs of many lands," "gay, lilting madrigals," and "lusty yodels and mountain calls" as well as "exquisite old motets and masses," and bragged of "record cross-country tour[s]" and large numbers of engagements. ${ }^{11}$

The Trapps soon become so well-known that advertisements for them all but disappeared from music magazines. ${ }^{12}$ As early as 1941, in fact, the New York Times considered it enough to note that a "second [Trapp Family] Christmas concert at Town Hall yesterday afternoon" had "followed the lines of the one a week earlier"; and that "Franz Wasner, as usual, conducted and there was an appreciative audience of 1,500" (New York Times, 22 December 1941). On the other hand, a flurry of feature articles foregrounded the family's escape from Hitler and distinctive brand of Christian togetherness. Observations about artistic issues were increasingly overshadowed by reports of a "remarkable family" that "has shown in every way how "All these things shall be added unto you"'-which "things," it appears, included "friends, the ability and opportunity to work, and success and joy" in the New World (MacDonald 1951,29). If any one 1940s American family anticipated the idealized televised families of the 1950s-families "so remarkably sharp in people's memories" that, even today, they often seem "fresher than memories of real life"-it was the Trapps. Like their imagined successors the Andersons, the Cleavers, and the Nelsons of Father Knows Best, Leave it to Beaver, and The Adventures of $O z z y$ and Harriet, the Trapps embodied "a world of warm-hearted, sensitive,

11 Musical America, 10 February 1943, 76.

12Nothing more than the name of the Trapp's ensemble and that of its director, Father Wasner, for example, appear on the full-page ads taken out by Columbia Artists Management in Musical America, February 1949, 35; and 1953, 308. 
tolerant Americans, a world devoid of anger and meanness of spirit and, of course, failure" (Halberstam 1993, 514).

It is difficult to document today precisely what the Trapps performed and where they performed it. Only a very few of their programs have been reprinted. One of these-again, a Christmas program-identifies an arrangement of three short pieces (for "Antique Instruments") and a Sonata by Sammartini (presented by a "Quintet of Recorders") as the evening's principal instrumental selections; shorter vocal works included Praetorius's "Es ist ein Ros' entsprungen," a Monteverdi madrigal, Holst's "Midwinter," and an arrangement of "The Holly and the Ivy." 13 Another program-unfortunately incomplete, but known to have been presented in 1943 at Boston's Jordan Hall-featured a song by John Dowland, transcriptions by Wasner of Tyrolean folk tunes, and a Trio for two recorders and viola da gamba composed by "Werner von Trapp." 14 In spite of their instrumental accomplishments, however, the Trapps were above all a vocal ensemble that sang (and played) music together largely for religious reasons. When they could, they stuck to canonical Christian compositions; a program they presented in 1948 at the Peabody Conservatory of Music, Baltimore, consisted of liturgical works by Bruckner, Jacob Handl, Mozart, and Victoria, a few instrumental pieces, and a few lighter religious numbers (Trapp 2003, unpaginated facsimile). Only after Schang became their manager-and then, not always-did they add American folksongs and other "foreign" music to their repertory.

The Trapps' travels within North America were unusually extensive. "A Quiz Program," the fifth chapter in A Family on Wheels, documents the children's detailed knowledge of American cities and small towns-knowledge acquired at first-hand (Trapp 1959, 45-53). So, apparently, did family souvenir albums, from which a few pages have survived and been reproduced (Anderson 1998, 56, 72-73). ${ }^{15}$ Yet, although Maria Trapp and her children prepared "several [different] programs for each season: one for the average public, one for schools, and one-more rarely sung-for the most serious music lovers" (Trapp 1959, 43), family concerts consisted mostly of reruns. "The Holly and the Ivy," for example-a number performed on both of their 1954 New York holiday concerts - had been presented for the first time, and in the same hall, some fifteen years earlier. ${ }^{16}$ "Silent Night" ended a great many performances-and not only at Christmas. The "Hawaiian Songs" that con-

13“The Trapp Family Singers," Musical America, 25 December 1940, 14. In all, the Trapps performed some 145 different works in the United States (Hochradner 2000, esp. 123-30). Many of these pieces were preserved for posterity on six single or multiple sets of phonorecords (Anderson 1998, 161-67).

14Reproduced in Hochradner 2000, 138. This article contains several other fragmentary programs.

15 Available information documents stops in such places as Kalispell, Montana; Logan, Utah; Santa Fe and Roswell, New Mexico; and Sioux City, Iowa; as well as Boston; Chicago; Edmonton, Alberta; and Montréal (Anderson 1998, 68-69, 105). In December 1980 a fire ravaged the Trapps' Vermont home and many souvenirs of their transcontinental tours were lost (Anderson 1986, 44-45). An attempt on the part of the present author to solicit information about the family's tours from Johannes Trapp, today the president of the family's lodge and other business enterprises, met with failure.

16“Trapp Family Singers," Musical Courier, 15 January 1954, 13. 
cluded a 1955 Honolulu concert followed "Innsbruck, ich muss dich lassen," one of the family's many "evergreens" (Trapp 2003, unpaginated facsimile).

Furthermore, except for their annual New York appearances, the Trapps visited a great many places only once. Their fame, in other words, was widespread but "brief" and "thin"-a situation compounded by their infrequent radio and television broadcasts, their limited appeal as recording artists, and the increasing attention they paid after 1944 to their music-camp activities. After "the Captain"-patriarch Georg, Baron von Trapp-died in May 1947, their ensemble increasingly included hired "outsiders." In the 1950s the Trapps toured Australia, New Zealand, Fiji, and the Hawaiian Islands. "We were gone half a year," Agathe von Trapp remembers, "and everyone except Mother had the feeling that it was our last big trip. We had come to the end of our inner resources and endurance.... It was time for a change" (Trapp 2003, 192). The family's last "regular" public performance took place in Concord, New Hampshire, on 26 January 1956.

\section{II}

Beyond these facts, information about the Trapp Family Singers as an ensemble is surprisingly hard to come by. An overwhelming majority of their performances took place in small towns, and back issues of small-town newspaper are difficult to obtain. Furthermore, the Trapps received virtually no contemporaneous attention from musicologists, even from specialists in Aufführungspraxis. Comparatively few reviews appeared in professional periodicals, and most of those that did appear-including squibs in Musical America and the Musical Courier during the later 1940s and early 1950s-mention only the family's New York performances. What we do know, however, suggests that the Trapps were celebrated especially for cohesion: as a vocal ensemble, to each other as "family," and to causes such as Allied victory in World War II and post-war Austrian relief efforts.

Early and mid-1940s magazine ads confirm that the Trapps or their managers relied on familial cohesion to sell tickets. Maria Trapp herself went out of her way to make this clear. In a packet of press release ${ }^{17}$ probably prepared in 1946, she is quoted as having concluded more than one concert with the following words:

And now, ladies and gentlemen, you have heard us sing and play together here on the stage, but I wonder how many of you realize that we are all members of a single family - father and mother, brothers and sisters, who not only make music together on the stage, but who live and work and worship together always. Here is my husband, the Captain, Baron Georg von Trapp, and with him our little son Johannes-they sing with us at home but not in public. Then come my seven daughters, Johanna, Hedwig, Agathe, Maria, Martina, Rosemary and Eleanore. And finally, there is our spiritual counselor,

17Hereafter "packet." The author would like to thank the University of Vermont for providing photocopies of this document. 
musical leader, and very good friend, Father Franz Wasner. Besides those you see here, there are two more members of our family, our older sons Rupert and Werner, of whom we are especially proud, because they wear the uniform of the United States Army and have given valiant service in helping to win the great victory of our country against the forces of evil and destruction. (packet)

"So one is introduced," the release concludes, "to the Trapp Family Singers, whose musical achievements are no less rare a joy to their hearers than is their inspiring service to an ideal of family life which is too fast becoming extinct" (packet).

As late as February 1942, excerpts from Boston Herald and New York Herald-Tribune reviews of Trapp performances published in Musical America emphasized "artistic integrity," "vocal balance," and "appropriate dynamic variegation and purity of intonation" (Musical America, 10 February 1942, 87). The following year, however, newspapers throughout the United States-the Albany Times-Union, the Fort Wayne [Indiana] Journal-Gazette, and the Syracuse Post-Standard among them-apparently emphasized "charm," "purity," and "simplicity" (Musical America, 10 February 1943, 76). ${ }^{18}$ Character, in other words, seems to have counted as much as-and perhaps more than-musical skills. Religious imagery abounded. The Toledo Blade, for instance, praised the family's "reverence" as well as "deep-rooted simplicity" and "rare loyalty to traditions and viewpoints that have been put out of fashion." The Washington News mentioned "love of a family, love of music, [and] love of God": sentiments "powerfully transferred" by the Trapps to members of their audience. The Louisville Times compared the Trapps to "Fra Angelico angels," who had miraculously "come to life" (packet).

Vocal blending-which is to say, musical cohesion-seems to have been the Trapps' greatest artistic asset; one critic described them as a "wholly united" as well as a "sincere" professional ensemble (quoted in Trapp 2003, 163). But the Trapps also enjoyed blending in private. They made Hausmusik even in pre-Anschluss Austria. Merely making music together was perceived by Maria Trapp as simultaneously enjoyable and moral. "A family which sings together, plays together, and prays together," she is quoted as claiming, "usually stays together" (MacDonald 1951, 15).

Collective, intimate, and especially familial music-making, which had figured in the Trapps' training under Wasner, became their specialty on stage and off. During the 1930s and early 1940s, again according to Maria Trapp, she and her children "discovered the intricate beauty of madrigals-the "home music' of the sixteenth and seventeenth centuries." Later, "we used many of Father Wasner's 'American' choral arrangements," which conveyed to U.S. audiences of the 1940s and 1950s a special sense of intimacy (Trapp 1959, 42-44). The Trapps may even have established their "Sing Weeks," or summer

18The same advertisement is reproduced in facsimile in Anderson 1998, 62. Another advertisement, this one undated, is headed "A Story Book Family" and "A Colorful Attraction" (Anderson 1998, 63). 
music camps, at Stowe, Vermont, largely because people wrote to them, asking how "we can do what you do; sing in our family?" (Anderson 1986, 41; italics added). In large part the "Weeks" won renown because the Trapps "created a homey setting" where everyone "joined in folk dancing sessions" and other activities. Only musical families were welcome; "no non-singing relatives" were permitted to "occupy [camp] space" (Anderson 1986, 41-42).

The Trapps' escape from fascism and their opposition to Hitler also contributed to their success. This was true especially in the United States after December 1941. As early as 1940, however, Maria regularly asked a favor of her audiences: "As often as you hear this song ['Silent Night'], please do one thing. Say a little prayer that our beautiful country, Austria, will rise again" (New York Times, 9 December 1940). ${ }^{19}$ Several years later, family members were photographed reading letters from soldiers stationed abroad (Musical America, 10 February 1945, 28). Two of the Trapps, as we have already seen, served with the American forces in Europe-a fact that several popular magazines, The Reader's Digest among them, were careful to mention and applaud (Murphy 1948; MacDonald 1951). Less frequently mentioned, however, was the Trapps' seeming indifference to the politics of pre-Anschluss Austria. Although anti-fascist and pro-Catholic, the Austrian "Ständestaat" of 1932-1938, led successively by Engelbert Dollfuß and Kurt Schuschnigg, was a dictatorship. The Trapps, however, were not so much opponents of dictators as they were patriotic Austrians and practicing Catholics. More than anything else, it was Hitler's religious policies (and bad taste!), in conjunction with Germany's outright annexation of Austria, that turned the Trapps against him and his regime (Trapp 1949).

Describing the Trapps' home-grown activities, Franz Wasner urged Americans to "turn to more active music-making" (Wasner 1949, 31). Intriguingly, Wasner's words recall American efforts on behalf of music "as a means of effecting national solidarity and buoying citizens' morale" during World War II (Goble 1999, 346). Organized in 1941 mostly by music educators, the American Unity Through Music program specifically encouraged "the playing and singing of songs that 'best embody the spirit and ideals of our United States"'; folk and pioneer songs-although not, of course, German and Japanese songs-were singled out as especially useful (Goble 1999, 348). At least one federal agency also called upon school-music programs to help build "'spiritual values and attitudes of mind' among the nation's populace" (Goble 1999, 347). The Trapps' wartime popularity and respectability may have been strengthened by their performances of "God Rest Ye, Merry Gentlemen" (British), "Sur la route de Dijon" (French), and "Waltzing Matilda" (Australian), as well as "Old Black Joe" and other American chestnuts (Hochradner 2000). The Trapps also programmed works by Bach, Brahms, Isaac, Palestrina, and Victoria: all of them born in what, during the war, were "Axis" nations. This last fact,

19An interesting choice of words: just as the Trapps professed loyalty to America, so-at least in this passage-does Maria call upon her listeners to profess loyalty of a kind to Austria. 
however, seems to have been overlooked at the time-a testimonial not only to the Trapps' patriotism, but to an understanding on the part of Americans everywhere that their countrymen and -women had exaggerated the dangers of "Hun" music during World War I.

At the same time, the Trapps remained "Austrian" through and through. They avoided American popular culture, never turning on a radio except to listen to news or classical-music broadcasts. Disdaining store-bought gifts, they made most of their own Christmas presents and all of their decorations. Maria and her children even insisted on wearing Austrian folk costumes wherever they went. In 1943, Life magazine marveled that "in native dress, which they have never changed for American clothes, the [Trapp] girls [do] all the heavy construction" on what became Cor Unum, the family's new, twentyroom Vermont estate, "even mixing and pouring cement for foundations" (Life, 8 November 1943, 128; italics added). ${ }^{20}$ Yet the Trapp girls, taking circumstances into account, were nothing if not "feminine." George Mosse has pointed out that "national and religious symbols helped to fix woman in her place" in nineteenth-century European culture (Mosse 1985, 97). Among America's wartime symbols of patriotic womanhood, however, was Rosie the Riveter: an icon anything but "restful." Like Rosie, the hard-working Trapp women embodied "respectability"; in every way they also served as "custodian[s] of tradition, who kept nostalgia alive" for society as a whole (Mosse 1985 , 97). After the war ended, however, Trapp press releases pointed out other, more conventionally feminine attributes, including the "bright dirndl costumes" the girls wore and the "several dozen white, frilly peasant blouses" daughter Hedwig washed, starched, and ironed each week (packet).

Finally, the Trapps contributed frequently and open-heartedly to charitable causes. At the beginning of December 1941, for example, they appeared with Gregor Piatigorsky at the Waldorf-Astoria Hotel on behalf of the Musicians Emergency Fund (New York Times, 2 December 1941). Earlier the same year they performed on behalf of the Lots for Little Thrift Shop, an organization "maintained for the benefit of several philanthropic organizations" (New York Times, 2 March 1941); the concert in question took place at the Convent of the Sacred Heart on East 91 st Street in Manhattan. More important financially, and certainly more influential insofar as their reputation was concerned, were the concerts they gave during and after 1945 on behalf of Austrian relief. A leaflet the family distributed on behalf of this cause contained appeals to patriotism, musical as well as national ("The country which gave to the world a Haydn, Mozart, Schubert, Johann Strauss-a 'Silent Night'-may perish if we don't all help together and act right now"), sought to educate as well as solicit ("everybody is informed about conditions in the larger European countries, but hardly anybody knows what is going on in Austria"), and professed Christian

20"The Captain," Maria's husband, apparently did little or no physical or mental work; he was too much the aristocrat. Nor, as we have seen, did he appear as a performer on stage with the rest of his family. Instead, in a brief obituary published after his death in 1947, Freiherr von Trapp was described as "manager and non-singing head of the Trapp Family Singers" [Time, 9 June 1947, 53]. 
attitudes toward charity and service (Trapp 1949, 276-77). For many musiclovers, the Trapp family's distinctive blend of good works, piety, and AustrianAmerican patriotism proved irresistible. So, too, for Roman Catholic officials. In 1949 the Vatican singled out Maria's relief efforts by awarding her the Benemerenti Medal, "a pontifical decoration ... conferred by Pope Pius XII" (New York Times, 16 November 1949).

Whether the Trapps were absolutely everything they stood for-cohesion (in this instance, a synonym for "togetherness"), cheerfulness, patriotism, and piety-is uncertain. Von Trapp Family, an Arts \& Entertainment "Biography" series television program, set out several years ago in part to debunk the Trapps' wholesome image. According to this program, Maria Trapp once locked up one of her daughters in order to prevent unsavory behavior as well as loss of family income. The girl eloped anyway. A physician who served on the medical staff of the University of Vermont Hospital met Maria on several occasions when she brought employees in for treatment. He remembers her as concerned but possessed of "a very gruff manner-not Julie Andrews!" 21

Also dubious are a few of Maria Trapp's reminiscences. Encountering throughout the American South "white" and "colored" rest rooms, waiting rooms, and seats on public buses, Maria claims at first to have assumed that "colored people ... choose to stay somewhat apart," and that she and her family "must respect their privacy" (Trapp 1959, 63). Her observations sound improbably naïve today. On the other hand, the Trapps apparently showed no racial bias in their musical dealings. "Catholics, Protestants and Jews, Negroes and whites"-all were welcome at the family's Vermont "Sings" (Murphy 1948, 59). Catholics they may have been-and many Protestant Americans are suspicious of "Romish" dangers - but the Trapps always presented themselves as the "right kind" of Americans: loyal, hard-working, generous, and apparently without religious bias of any significant kind.

In recent years a certain amount of "values" fun has been had at the Trapps' expense. In 1993, for example, the National Review published "Trapp Family Christmas," in which a beleaguered "president of the Planned Parenthood Association" who thinks having "a big family would be such fun" during the holidays finds herself struggling to recreate the elaborate holiday festivities described in Maria's autobiographies (Heath 1993). Since 1999, "sing-along" screenings of The Sound of Music have taken place in Toronto, New York, and other large North American cities. Audience members attend these events dressed up as phrases from Hammerstein's song lyrics, sigh when Julie Andrews embraces Christopher Plummer, and hiss the Nazis. ${ }^{22}$ Irreverent, even transgendered participation is taken for granted. ${ }^{23}$ Much of the harshest "Trapp" criticism, however, has been aimed at the movie, especially ways in

21 Bruce Birch, M.D., in an email communication with the author, 15 April 2003.

22 See http://archives.cnn.com/2000/SHOWBIZ/Movies/09/07/singalong.song and similar web sites.

23See the illustrations at http://www.dvdreview.com/html/sound_of_music_event.shtml and other sites. 
which it misrepresents Austrian history and American politics (e.g., Wagnleitner 2000, 441-49).

In spite of attacks and ridicule, the real-life Trapps were almost universally accepted throughout the 1940s and 1950s as icons of physical, mental, and moral purity, patriotism, and especially familial harmony. The family's very first Musical America ad quotes the St. Paul, Minnesota, Pioneer Press to the effect that "only a real health of body and mind and spirit could communicate the sweet naturalness which characterizes all that these singers have to offer" (Musical America, 1 February 1940, 57). Years later, Time magazine quoted Maria Trapp concerning the energy and consistency of purpose she, her husband, and her children brought to their many undertakings. "This," she proudly affirmed-referring to virtually everything they did, on and off tour-“is family life!" (Time, 18 July 1949, 47). Similar observations appeared even in reviews of Trapp Family musical performances. Ostensibly evaluating two Town Hall Christmas concerts, a critic for the Musical Courier quickly bypassed issues of vocal and instrumental skill, programming choices, the "quaint dress" worn by ensemble members, and their use of "candle- lanterns" in favor of describing real-life Trapp gift-giving games and Twelfth Night celebrations (Craig 1950, 14).

\section{III}

What musical training the Trapps' had came mostly from Wasner, who emphasized the importance of vocalizing, discouraged the use of pianos because accompaniment interferes with good "ear-building," and explained how singing canons can build individual self-confidence as well as provide participants with "the satisfaction of hearing the total result that comes from the polish of individual efforts" (Wasner 1949, 27). More important, perhaps, was the Trapps' own belief that each of them should integrate his or her "singing and music-making with ... everyday life, with holidays and feasts, with religion and fun" (Wasner 1949, 31).

In spite of Wasner's instruction and their own, extra-musical iconic prestige, the Trapp Family Singers were occasionally criticized as performing artists. A contributor to Musical America - who nevertheless called one of the family's 1940 Town Hall concerts "memorable"-asserted that "[n]one of [the ensemble's] members has a voice of any particular quality" (Musical America, 25 December 1940, 14). The same critic cast aspersions on the "archeological interest" of their instrumental numbers, which on the occasion in question included a sonata by Sammartini, and compared the "tootling recorders" they played to the sounds of an "old-fashioned hand organ, now happily almost extinct" (Musical America, 25 December 1940, 14). ${ }^{24}$ Years later, another

24Another critic referred to Johannes Trapp's recorder playing as "competent," the instrumental music performed by him and several of his siblings as merely "pleasant" [Musical Courier, 15 January 1954, 13]. A later Trapp family performance of a Telemann trio sonata was described as "beguiling" ["Trapp Family Singers," Musical America, 1 January 1955, 35]; by this time, however, the oldest children had been replaced by non-Trapp professionals. 
critic pointed out that an arrangement of Wolf's Geistliche Chöre, "sacred songs quite beautiful in their part writing," proved unsuitable for the Trapps. Evidently Wolf's "harmonic idiom, with its chromaticism and enharmonic shifts, does not lend itself too well to unaccompanied singing.... [and p]itch deviations from the tempered scale, natural to unaccompanied singing," obscured the composer's "lovely harmonic progressions" (Musical America, 1 January 1950,20$).{ }^{25}$

Sound recordings confirm the family's informal training and real weaknesses as performers. The Original Trapp Family Singers, available today on compact disk, documents the artistry of a talented "amateur" ensemble rather than full-fledged "professionals"-at least in the sense that Marian Anderson, Bing Crosby, Arthur Fiedler, Mitch Miller, Lawrence Welk, and the Philadelphia Orchestra as conducted by Eugene Ormandy (all of whom appeared with the Trapps, either in person or on recordings) were professionals. Family members sang well, but their individual voices were less than first-rate and their pitch sometimes slipped. That the Trapps also performed with taste, conviction, and sincere devotion to the cause of "good music," moral as well as beautiful, deserves praise from those who share a "fully justified impatience with the dogged pedantry" that has long driven advocates of "authentic" performance practices (Kivy 1995, 19). Small wonder that many critics considered the family's Christmas carols and folk songs their "most effective" selections (Musical America, 1 January 1955, 35).

Nevertheless, the Trapps made two substantial contributions to the musical culture of their adopted land. The first involved what Wasner called "the authentic American popular music - the folk songs of this continent." "Get to know the American heritage of true folk songs," he insisted, "the truly popular music of this continent, born of the people-the folk songs of New England and of the South, authentic cowboy songs, and authentic Negro spirituals" (Trapp 1959, 31). These attitudes are reflected in Maria Trapp's disparaging references to "'hit' tunes," which she was convinced "affect the minds, the character, the emotional life of our growing children. Psychiatrists are raising their voices in warning, as juke-boxes, radio and television, going from dawn to dusk, help spread the poison of synthetic, artificial, rhythmical noise." "We found it an uphill battle to make the American folk song known in its own right," she reported (Trapp 1959, 44).

It was a battle she herself helped win-on behalf of her family and, it would seem, in unconscious support of multicultural additions to American music education programs (Volk 1993). And it was a battle she lost, at least insofar as posterity has been concerned. By the time rock ' $n$ ' roll became a force to

25The Trapps occasionally experimented with even more challenging compositions. In 1953 they presented Peter Warlock's Corpus Christia-"enough in itself," one critic observed, "to bring a Warlockian like myself to the concert" [Musical America, 1 January 1954, 23]. Audiences, however, mostly came for the Christmas carols-especially "Silent Night," when the Trapps "all quietly moved off the stage, their lanterns blinking peacefully in the semi-darkness" ["Trapp Family Singers," Musical America, 1 January 1955, 35]. 
contend with-1956 was the year Elvis Presley "broke through"- the Trapps had quit the concert platform. As John Lennon is supposed to have said, "Before Elvis there was nothing" (quoted in Halberstam 1993, 457). Hyperbole, of course, but Lennon's words make sense insofar as the Trapps' musical reputation is concerned. Their fame evaporated as soon as rock began to supplant a great many other kinds of popular music.

The Trapps' second substantial contribution involved the recorder, an instrument scarcely known in the United States prior to the 1940s. Claims that a 1950s-1960s recorder "revival" was "largely due to the Trapp family!" (MacDonald 1951, 25) may be exaggerated, but family members did publish their own recorder method (Hunt 1976); certainly they helped renew interest in that instrument (Haskell 1988, 106, 119). Kathy Sherrick, administrative director of the American Recorder Society, recalls that her brother, twin sister, best friend, and herself "all taught ourselves how to play the recorder" using the Trapps' method book. As Sherrick explains:

I started a small beginner group here in St. Louis. Most had started playing the recorder decades ago with the same Trapp Family Singers method book and still have them. We could have chosen other method books that seem more "modern" or have a play along CD but we still like the Trapp Family Singers method book and the music that it contains. You can see that there are still fans of the Trapp Family Singers around the country! ${ }^{26}$

Of course, the most obvious, albeit "unmusical," monument to their North American career is the up-scale Trapp Family Lodge and the Vermont housing developments that currently surround it. Supervised by Johannes Trapp, Maria's youngest child, the Lodge entrance bears a sign reading "A Little Bit of Austria, and a Lot of Vermont." Visitors can experience "ethnicity" in the midst of thoroughly white, Christian, middle-class American luxury. Bauernwurst, "Blue Danube" china, and dirndls exist side by side with ample parking and New England "photo ops." But little of this has anything directly to do with music.

Nor, in a sense, does a recent Trapp Family "revival." In 2002, four descendents of the original Singers-siblings Amanda, Justin, Melanie, and Sofia Trapp-began concertizing in North America; in 2004 they also performed in Australia. Ironically, this new ensemble, carefully outfitted in dirndls and lederhosen, specialize in Sound of Music numbers rather than masses and motets. ${ }^{27}$ Not that anybody seems to care. Even Agathe von Trapp, who still uses her aristocratic particle and who "cried" when she first saw The Sound of Music, has made her peace with Hollywood's misrepresentations. "Who am I, then, to criticize the movie? I finally learned to separate the memories of my life from the screenplay.... I began to see that while all the

26Kathy Sherrick, in an email communication with the author, 26 April 2005.

27 Another Trapp descendent, Elisabeth von Trapp, performs everything from Gregorian chant to "country and contemporary folk." See http://www.christkindlmarkt.org/04VonTrapps.asp, http://www.holidayswithkids.com.au/?p=565, and http://www.elisabethvontrapp.com/bio.htm. 
details may not be correct, the creators of The Sound of Music were true to the spirit of my family's story" (Trapp 2003, 202; italics in the original).

The real-life Trapps have long been old-hat. The explosion of mid- and later 1950s American popular music, Little Rock, the space program, and other upheavals unquestionably contributed to their obscurity. Yet, to this day, no other ensemble has presented works by the likes of Bach, Isaac, Josquin, Lasso, Palestrina, and the English, German, and Italian madrigalists as often and in as many parts of North America as did the Trapps. Certainly no other group with their drawing power and popular reputation. Even so, music was not altogether what the Trapps represented to the thousands of men, women, and children who heard them and read about them during the late 1930s, 1940s, and 1950s. To these people, and many others who watched the family only on television or learned of them only through their recordings, the Trapps embodied the values often associated with and embraced by Canadians and Americans of Days Gone By: patriotism and charity as well as "faith [and] obedience to God's will, and gratitude - not only to success, but to adversity as well." For their audiences they were, truly if only briefly, a "Wonder Family": of "singers," yes, but-above all-a family (MacDonald 1951,15). A great many North Americans cherish their values today.

\section{REFERENCE LIST}

Anderson, William T. 1986. "America's Trapp Family." American History Illustrated 21/8 (December): 36-45.

Anderson, William, with David Wade. 1998. The World of the Trapp Family. Davison, MI and Stowe, VT: Anderson Publications.

Boriga, Mary Francis, O.S.F. 1980. One Family Sings: A Two-act Play with Music, Based on the Story of the Trapp Family Singers. Evanston, IL: Row, Peterson.

Cook, Nicholas. 2003. "Music as Performance." The Cultural Study of Music, ed. Martin Clayton et al: 204-14. New York: Routledge.

Craig, Mary. 1950. "Silhouettes: Yule Customs Inspire Trapp Family Concerts." Musical Courier 142 (15 December): 14-15.

Goble, James Scott. 1999. Ideologies of Music Education: A Pragmatic, Historical Analysis of the Concept "Music" in Music Education in the United States. Dissertation: University of Michigan.

Halberstam, David. 1993. The Fifties. New York: Fawcett Columbine.

Haskell, Harry. 1988. The Early Music Revival: A History. London: Thames \& Hudson.

Heath, Aloise Buckley. 1993. "A Trapp Family Christmas." National Review 45/25 (27 December): 46-48. Reprinted with the subtitle "An NR Tradition" in the National Review 52/25 (31 December 2000): 42-45.

Hochradner, Thomas. 2000. "Zum Repertoire der 'Trapp Family Singers'." "The Sound of Music: zwischen Mythos und Marketing, ed. Ulrike Kammerhofer-Aggermann et al.; 115-39. Salzburg: Salzburger Landesinstitut für Volkskunde. 
Hunt, Edgar. 1976. The Trapp Family Recorder Method. A New, Complete Method of Instruction for the Recorder ... (rev. ed.). London: Schott.

The Internet. All web pages were last accessed on 20 May 2005.

Kershaw, Baz. 1992. The Politics of Performance: Radical Theater as Cultural Intervention. New York: Routledge.

Kivy, Peter, 1995. Authenticities: Philosophical Reflections on Musical Performance. Ithaca, NY and London: Cornell University Press.

Knapp, Raymond. 2004. "History, 'The Sound of Music,' and Us." American Music 22: 133-44.

Life magazine. 1943-1949.

MacDonald, Ruth. 1951. "The 'Wonder Family' of Singers." Southwestern Musician 18 (December): 15, 25, 28-29.

Manning, R. D. 2001. "Merry Christmas!" A Four-act Melodramatic Musical Comedy Screenplay Sequel to "The Sound of Music" / Based Upon the Writings of Maria Augusta von Trapp, rev. ed.. Lethbridge, Alberta [Canada]: Salt-of-the-Earth.

Metten, Patricia. 1981. The Power of Family: Featuring the Story of the Trapp Family. Antioch, CA: Eagle Systems International.

Moltke, Johannes von. 1996. "Trapped in America: The Americanization of the 'Trapp-Familie,' or 'Papas Kino' Revisited." German Studies Review 19: 455-78.

Mosse, George L. 1985. Nationalism and Sexuality: Respectability and Abnormality in Modern Europe. New York: Howard Fertig.

Murphy, T. E. 1948. “The Lively Trapp Family.” Reader's Digest 52 (January): 55-59.

Musical America. 1938-1955.

The Musical Courier. 1949-1957.

New York Times. 1938-1959.

The Original Trapp Family Singers, conducted by Franz Wasner. New York: BMG Entertainment, 1998. Digitally remastered from acoustic recordings made between 1938-1940.

"Packet" = The Trapp Family Singers ["Press Preview" materials]. No publication information. Wilcox Collection, University of Vermont Library.

Saffle, Michael. 2003. "Traveling Tales: The Trapp Family Singers and Maria von Trapp's Post-World War II Immigration Narratives." Ports of Call: Central European and North American Culture/s in Motion, ed. Susan Ingram et al.; 67-100. Frankfurt and New York: Peter Lang.

Small, Christopher. 1998. Musicking: The Meanings of Performing and Listening. Hanover, $\mathrm{NH}$ and London: Wesleyan University Press.

Teixeira, Ruy. 2002. "Political Trends among American Parents: The 1950s to 1996." Taking Parenting Public: The Case for a New Social Movement, ed. Sylvia Ann Hewlett et al.; 119-37. Lanham, MD: Rowman \& Littlefield.

Time magazine. 1947-1949. 
Trapp, Agathe von. 2003. Memories Before \& After "The Sound of Music": An Autobiography. Franklin, TN: Hillsboro.

Trapp, Maria Augusta. 1949. The Story of the Trapp Family Singers. Philadelphia: Lippincott.

1952. Yesterday, Today, and Forever: The Religious Life of a Remarkable Family. Garden City, NY: Doubleday.

. 1955. Around the Year with the Trapp Family. New York: Pantheon. 1959. A Family on Wheels: Further Adventures of the Trapp Family Singers. Philadelphia: Lippincott.

. 2000. Let Me Tell You About my Savior [posthumous]. Green Forest, AR: New Leaf.

Volk, Terese M. 1993. History of Multicultural Music Education in the Public Schools of the United States, 1900-1990. Ph.D. diss., Kent State University.

Von Trapp Family: Harmony and Discord. 1996. New York: Arts and Entertainment Network; distributed by New Video Group. VHS videotape; 50 minutes.

Wagnleitner, Reinhold. 2000. "The Sound of Forgetting Meets the United States of Amnesia: An Introduction to the Relations between Strange Bedfellows." "The Sound of Music: zwischen Mythos und Marketing," ed. Ulrike Kammerhofer-Aggermann et al.; 441-49. Salzburg: Salzburger Landesinstitut für Volkskunde.

Ware. T. Porter, and Thaddeus C. Lockard, Jr. 1980. P. T. Barnum Presents Jenny Lind: The American Tour of the Swedish Nightingale. Baton Rouge and London: Louisiana State University Press.

Wasner, Franz. 2000. "'I can't say I liked being a celebrity much at all.' "Franz Matthias Wasner, der Dirigent der Trapp Family Singers, in Dokumenten und Erinnerungen seines Neffen." "The Sound of Music": zwischen Mythos und Marketing, ed. Ulrike Kammerhofer-Aggermann et al.; 141-70. Salzburg: Salzburger Landesinstitut für Volkskunde.

Wasner, Franz [Matthias]. 1949. "The Trapp Family: Music in the Home." Musical America 69 (15 December): 27, 31.

Wilhelm, Hans. 1983. The Trapp Family Book. London: Heinemann.

Wilson, John S. 1959. "The Trapps-After 'The Sound of Music'." New York Times Magazine (13 December): 74-75.

Zechner-Kamberger, Ulrike. 2000. "Die Familie Trapp-Vergangenheit und Gegenwart." "The Sound of Music": zwischen Mythos und Marketing, ed. Ulrike Kammerhofer-Aggermann et al.; 99-113. Salzburg: Salzburger Landesinstitut für Volkskunde.

\section{Abstract}

Overlooked or ignored for decades by music historians and specialists in performance practices, the real-life Trapp Family Singers achieved enormous success especially in Canada and the United States during the late 1930s, 1940s, 
and early 1950s through their appeal to-and consequent reception in terms of- "family values." These values included, but were not altogether limited to, the Trapp's Christian faith, patriotic activities, and contributions to charitable causes, as well as the wholesome image associated with the family's private lives, their Vermont "Sing Weeks," and their more than 1,800 estimated concert appearances.

\section{Résumé}

Pendant des décennies, les historiens de la musique et les spécialistes de la pratique musicale ont négligé ou ignoré les chanteurs de la famille Trapp. Pourtant, ceux-ci ont obtenu un succès retentissant tout au long des années 1930, 1940 et le début des années 1950, aussi bien au Canada qu'aux États-Unis, en raison des « valeurs familiales » qu'ils véhiculaient. Ces valeurs comprenaient, entre autres, la foi chrétienne des Trapp, les activités de nature patriotique ou caritative, ainsi que la saine représentation rattachée à la vie privée de cette famille, leurs « semaines vocales » et plus de 1800 concerts réalisés publiquement. 